\title{
Bu-2313, A NEW ANTIBIOTIC COMPLEX ACTIVE AGAINST ANAEROBES I. PRODUCTION, ISOLATION AND PROPERTIES OF Bu-2313 A AND B
}

\author{
Hiroshi Tsukiura, Koji Tomita, Minoru Hanada, Seikichi Kobaru, \\ Mitsuaki Tsunakawa, Kei-IChi Fujisawa and Hiroshi Kawaguchi \\ Bristol-Banyu Research Institute, Ltd., Meguro, Tokyo, Japan
}

(Received for publication September 12, 1979)

\begin{abstract}
An unidentified oligosporic actinomycete strain, No. E864-61, produced two new antibiotics, Bu-2313 A $\left(\mathrm{C}_{27} \mathrm{H}_{35} \mathrm{NO}_{9}\right)$ and $\mathrm{Bu}-2313 \mathrm{~B}\left(\mathrm{C}_{26} \mathrm{H}_{33} \mathrm{NO}_{9}\right)$. Bu-2313 $\mathrm{A}$ and $\mathrm{B}$ each exhibited a broad antibiotic spectrum against Gram-positive and Gram-negative anaerobic bacteria, and showed in vivo activity against experimental infections produced by $B$. fragilis and $C$. perfringens. $\mathrm{Bu}-2313$ also inhibited some aerobic bacteria such as streptococci. $\mathrm{Bu}-2313 \mathrm{~B}$ was approximately two-fold more active than $\mathrm{Bu}-2313 \mathrm{~A}$.
\end{abstract}

With the increasing awareness of the role of anaerobic infections in clinical medicine, effective and nontoxic agents active against anaerobic organisms are needed. Benzylpenicillin is considered to be the drug of choice for many anaerobic infections ${ }^{1)}$ except for those caused by Bacteroides fragilis, the single most common anaerobic organism found in clinical specimens ${ }^{2)}$. As compared with other anaerobes, members of this species are relatively resistant to many antibiotics.

In our antibiotic screening program using $B$. fragilis as one of the assay test organisms, an oligosporic actinomycete strain was found to produce a new antibiotic complex designated as Bu- 2313 . It was extracted from the fermentation broth and separated into two components A and B. Both components showed antibiotic activity against a variety of anaerobic bacteria as well as some aerobic microorganisms. The structures of Bu-2313 A and $\mathrm{B}$ have been determined ${ }^{3)}$, indicating that they belong to the acyltetramic acid group of antibiotics which also includes streptolydigin ${ }^{4)}$ and tiranda$\operatorname{mycin}^{5)}$.

This paper reports on the production, isolation, physico-chemical and biological properties of Bu-2313 A and B.

\section{Producing Organism}

The aerobic actinomycete strain, No. E864-61, produced aerial spore chains consisting of a varied number of spores $(1 \sim 8)$. The color of the aerial mycelium was initially white, later turning to dull bluish green or light greyish green with abundant sporulation. Two types of pigment, violet and dark green, were produced in agar media. The spores were spherical to oval in shape, $0.6 \sim 1.2 \mu \mathrm{m}$ in size, and had a smooth surface. Aerial hyphae were occasionally spiralled and coiled in several to ten turns. The substrate mycelium did not become fragmented within a week at $37^{\circ} \mathrm{C}$. The growth of strain E864-61 was inhibited by sodium chloride. It produced no melanoid pigment and grew at $20 \sim$ $50^{\circ} \mathrm{C}$ but not at $55^{\circ} \mathrm{C}$.

The cell-wall of strain E864-61 was found to contain meso-diaminopimelic acid, glutamic acid and alanine. Galactose and a small amount of rhamnose were contained in the whole cell hydrolyzate. 
Strain E864-61 resembles the actinomycetes genera of Microtetraspora, Micropolyspora, Saccharomonospora, Thermomonospora and Actinomadura in some of the morphological and biochemical properties including the presence of meso-diaminopimelic acid in the cell wall. Results of further taxonomic studies on strain E864-61 will be published elsewhere.

\section{Antibiotic Production}

A well-grown agar slant culture of strain E864-61 was used to inoculate vegetative medium containing 3\% glucose, $3 \%$ soybean meal, $1 \%$ corn steep liquor and $0.5 \% \mathrm{CaCO}_{3}$. The media $\mathrm{pH}$ was adjusted to 7.0 before sterilization. The seed culture was incubated at $34^{\circ} \mathrm{C}$ for 3 days on a rotary shaker $(250 \mathrm{rpm})$ and $2 \sim 3 \mathrm{ml}$ of the growth transferred to a 500-ml Erlenmeyer flask containing 100 $\mathrm{ml}$ of fermentation medium composed of $3 \%$ sucrose, $3 \%$ linseed meal, $0.3 \%\left(\mathrm{NH}_{4}\right)_{2} \mathrm{SO}_{4}, 0.003 \%$ $\mathrm{ZnSO}_{4} \cdot 7 \mathrm{H} / \mathrm{O}$ and $0.5 \% \mathrm{CaCO}_{3}$. The broth $\mathrm{pH}$ gradually rose over the course of shaking fermentation at $28^{\circ} \mathrm{C}$ and reached $8.1 \sim 8.8$ after $4 \sim 7$ days, when the peak of antibiotic production was attained. The antibiotic activity in the fermentation broth was determined by a paper disc-agar plate method using Bacteroides fragilis A20928 as a test organism. The organism was grown on GAM agar plate (Gifu anaerobe medium, Nissui, Tokyo) under anaerobic condition using GasPak generators (BBL, Cockeysville, Md.).

Fermentation studies were also carried out in stir jar fermentors and tanks. In one of the examples, 110 liters of seed culture was inoculated to 1,500 liters of fermentation medium in a 2,500-liter tank containing 3\% glucose, $3 \%$ soybean meal, $1 \%$ corn steep liquor and $0.5 \% \mathrm{CaCO}_{3}$. The tank was operated at $31^{\circ} \mathrm{C}$ with stirring at $200 \mathrm{rpm}$ and an aeration rate at 1,000 liters/min. The fermentation was continued for 72 hours, at which time the broth $\mathrm{pH}$ was 8.2 and the antibiotic potency maximal.

\section{Isolation and Purification}

The fermentation broth was filtered with filter aid and the mycelial cake washed with water. The filtrate was combined with the wash, adjusted to $\mathrm{pH} 8.3$ and applied to a column of high-porous adsorption resin (Diaion HP-20). The column was washed successively with water and $40 \%$ aqueous methanol, and then developed with $95 \%$ aqueous methanol. Active fractions were combined and concentrated in vacuo to an aqueous concentrate. The wet mycelial cake obtained above was suspended in methanol and extracted with stirring. This was repeated twice and the combined methanol extract was concentrated in vacuo. The two aqueous concentrates obtained from the HP-20 eluate and the mycelial cake extract were combined and further evaporated in vacuo, and the activity in the concentrate was extracted twice with ethyl acetate. The extract was concentrated in vacuo to dryness to leave an oily solid ( $c a .20 \%$ purity), which was dissolved in a mixture of ethyl acetate and methanol (20: 1) and applied to a column of activated carbon. The column was developed with the same solvent mixture. The active eluates were combined and concentrated in vacuo to give a dark brown solid, which was crystallized from hot methanol to yield a brownish yellow crystalline powder $(60 \sim 70 \%$ purity).

The crystalline material thus obtained was a complex of Bu-2313 A and $\mathrm{B}$, whose separation was achieved by Diaion HP-20 chromatography: The solid was dissolved in $90 \%$ aqueous methanol and the solution applied on a column of HP-20 resin. The column was developed with $80 \%$ aqueous methanol to give two active fractions. From the concentrate of the first active fraction, Bu-2313 B was 
obtained as pale yellow needle-like crystals which were recrystallized twice from methanol to give an analytically pure preparation. The second active eluate gave a mixture of components $\mathrm{A}$ and $\mathrm{B}$ which was separated by silica-gel column chromatography developed with chloroform. Pure crystals of Bu-2313 A were obtained, after recrystallization from methanol, from the fastmoving fractions, and an additional amount of $\mathrm{Bu}-2313 \mathrm{~B}$ recovered from the latter part of the eluates. Approximately $11 \mathrm{~g}$ of $\mathrm{Bu}-2313 \mathrm{~A}$ and $110 \mathrm{~g}$ of $\mathrm{Bu}-2313 \mathrm{~B}$ were isolated from 1,500 liters of fermentation broth.

\section{Physico-chemical Properties}

Bu-2313 A and B are acidic substances isolated as pale yellow crystals. They are readily soluble in most organic solvents such as lower alcohols, ethyl acetate, chloroform and benzene, slightly soluble in hexane and alkaline water, and practically insoluble in water. They are stable in acidic solution but less so in alkaline solution, losing activity in $0.1 \mathrm{~N} \mathrm{NaOH}$ solution when held overnight at room temperature. Both components react positively with ferric chloride but give negative reactions in ninhydrin, anthrone, SAKAGUCHI and TOLLEN's tests. Bu2313 A and B can be differentiated by TLC, IR and NMR spectra as described below.

Bu-2313 A melts at 116 $118^{\circ} \mathrm{C}$ and is optically active: $\left.[\alpha]_{\mathrm{L}}^{2 \mathrm{~b}}-58^{\circ}(c) 0.5, \mathrm{MeOH}\right)$. It showed a $\mathrm{pKa}^{\prime}$ of 5.2 in $50 \%$ aqueous ethanol solution with a titration equivalent of 519 . The
Table 1. UV spectra of $\mathrm{Bu}-2313 \mathrm{~A}$ and $\mathrm{B}$.

\begin{tabular}{l|l|l}
\hline \multirow{2}{*}{ Solvent } & \multicolumn{2}{|c}{$\lambda_{\text {max }}$ in $\mathrm{nm}\left(\mathrm{E}_{1 \mathrm{~cm}}^{1 \%}\right)$} \\
\cline { 2 - 3 } & \multicolumn{1}{|c}{$\mathrm{Bu-2313 \textrm {A }}$} & \multicolumn{1}{|c}{$\mathrm{Bu}-2313 \mathrm{~B}$} \\
Ethanol & $245(170)$ & $239(170)$ \\
& $295\left(212, \mathrm{sh}^{*}\right)$ & $295(225, \mathrm{sh})$ \\
& $355(509)$ & $351(525)$ \\
& $375(390, \mathrm{sh})$ & $370(420, \mathrm{sh})$ \\
$0.01 \mathrm{~N} \mathrm{HCl}-$ & $242(170)$ & $237(170)$ \\
$95 \% \mathrm{EtOH}$ & $358(645)$ & $353(668)$ \\
& $375(555, \mathrm{sh})$ & $370(580, \mathrm{sh})$ \\
$0.01 \mathrm{~N} \mathrm{NaOH}-$ & $262(375)$ & $253(345)$ \\
$95 \% \mathrm{EtOH}$ & $286(393)$ & $286(411)$ \\
& $337(430)$ & $331(467)$ \\
\hline
\end{tabular}

* shoulder
Fig. 1. Ultraviolet absorption spectra of Bu-2313 A.

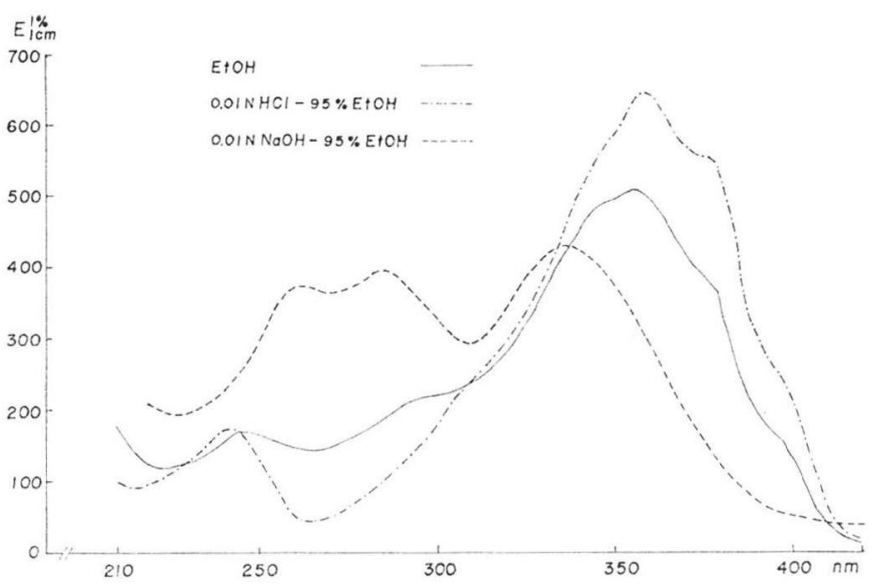

Fig. 2. Ultraviolet absorption spectra of Bu-2313 B.

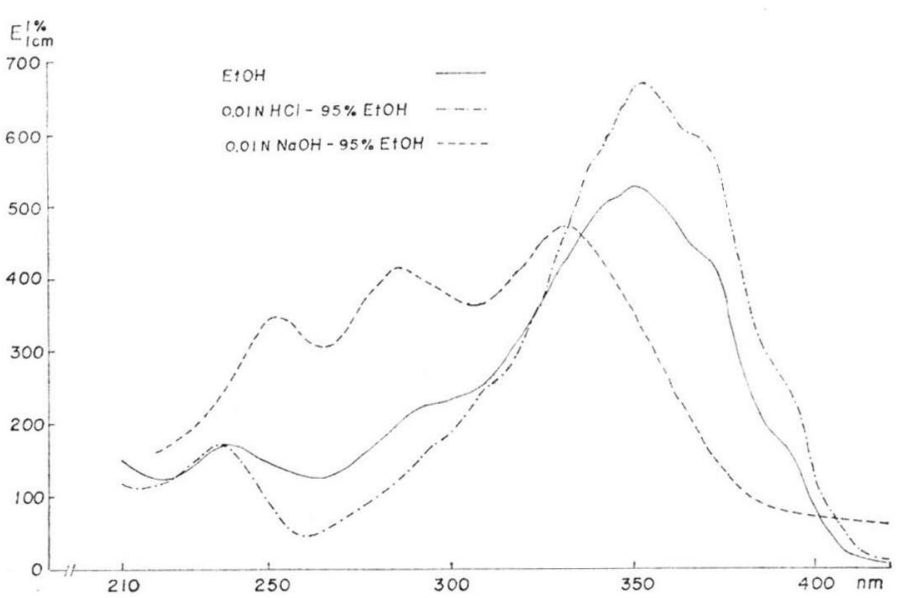


Fig. 3. Infrared absorption spectrum of Bu-2313 A.

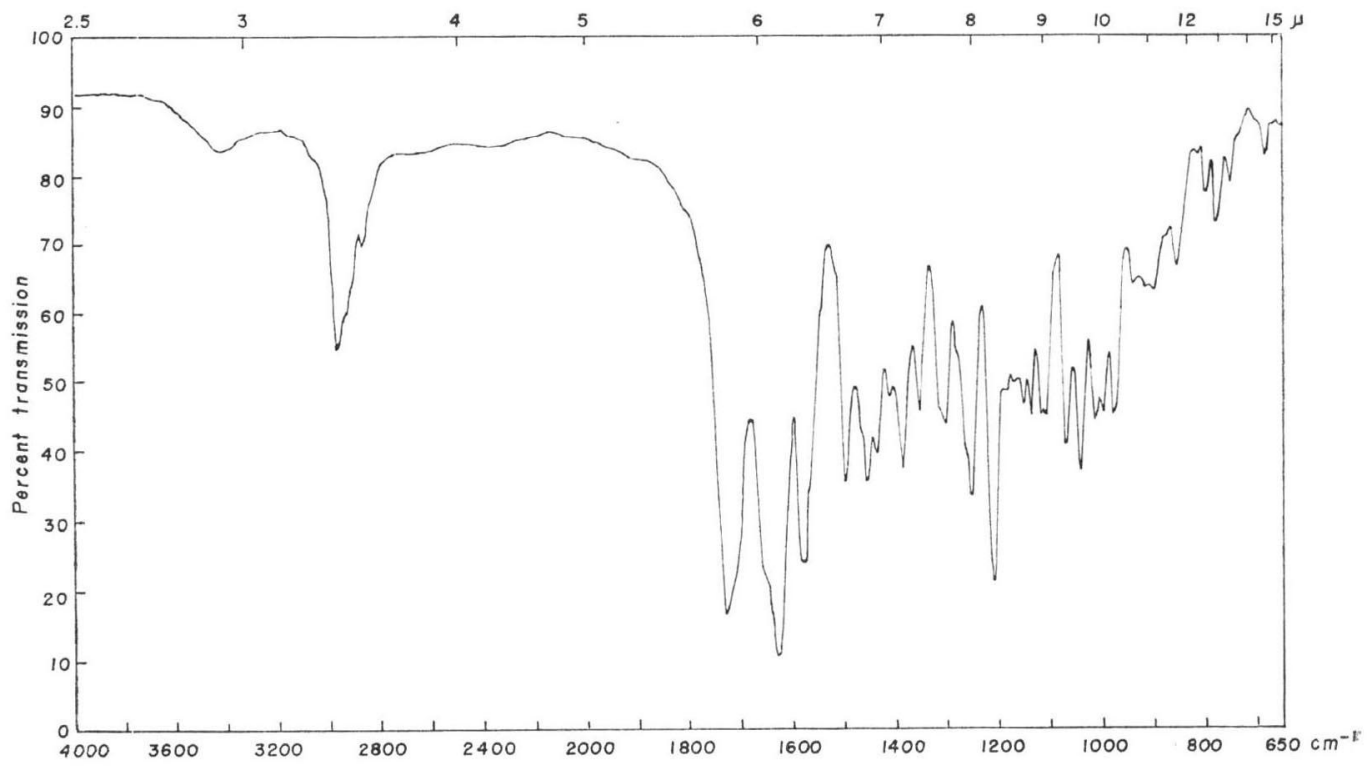

Fig. 4. Infrared absorption spectrum of Bu-2313 B.

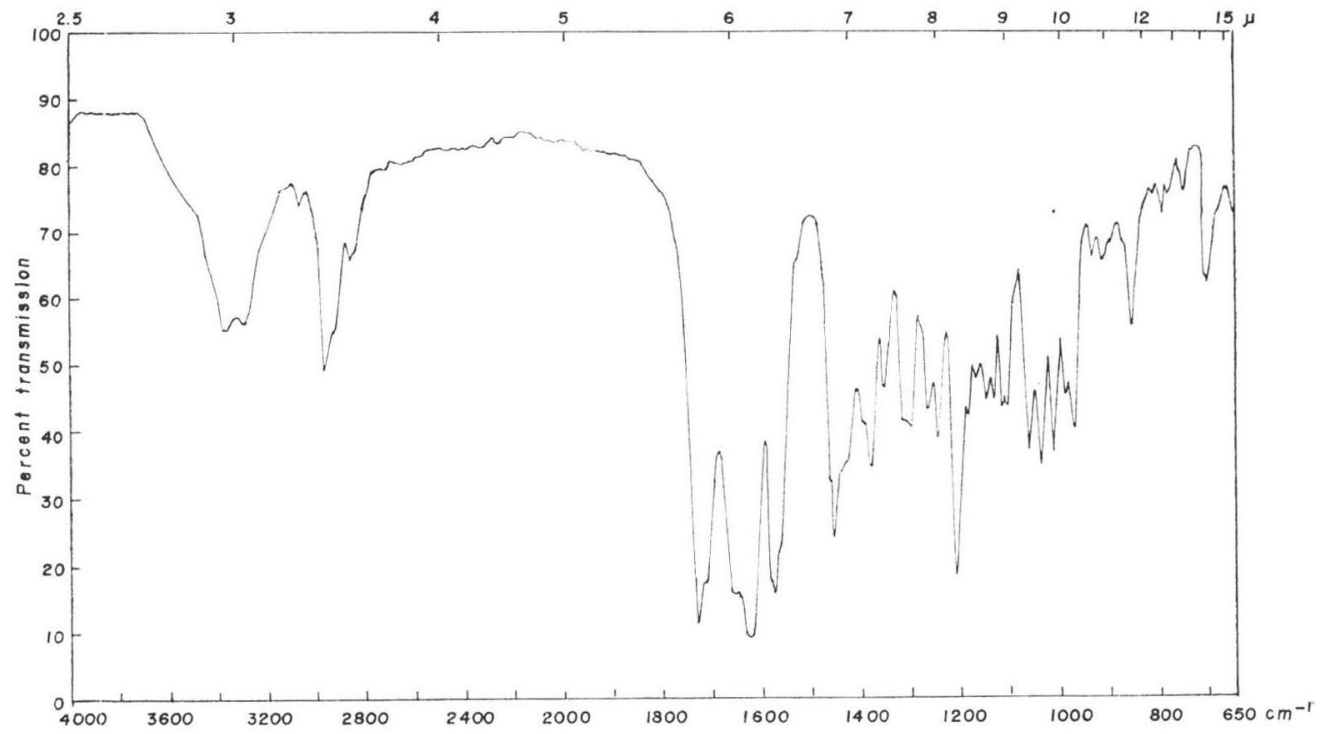

mass spectrum of $\mathrm{Bu}-2313 \mathrm{~A}$ gave a molecular ion peak at m/e 517 .

Anal. Calc'd for $\mathrm{C}_{27} \mathrm{H}_{35} \mathrm{NO}_{9}$ : C 62.65, H 6.82, N 2.71, O 27.82.

Found: C 62.57, H 6.64, N 2.60, O 28.19 (by difference).

Bu-2313 B melts at $160 \sim 162^{\circ} \mathrm{C}$ and its optical rotation is $[\alpha]_{1}^{26}-69.9^{\circ}(c 0.3, \mathrm{MeOH})$ and $-34.9^{\circ}$ $\left(c 0.93, \mathrm{CHCl}_{3}\right.$ ). It showed a $\mathrm{pKa}^{\prime}$ of 4.9 in $50 \%$ aqueous ethanol solution with a titration equivalent of 509 and gave a molecular ion peak at $m / e 503$ in the mass spectrum.

Anal. Calc'd for $\mathrm{C}_{26} \mathrm{H}_{33} \mathrm{NO}_{9}$ : C 62.03, $\mathrm{H} 6.56, \mathrm{~N} 2.78, \mathrm{O} 28.63$.

Found: C 61.77, H 6.80, N 2.65, O 28.78 (by difference). 
Fig. 5. NMR Spectrum of $\mathrm{Bu}-2313 \mathrm{~A}\left(60 \mathrm{MHz}\right.$ in $\left.\mathrm{CDCl}_{3}\right)$.

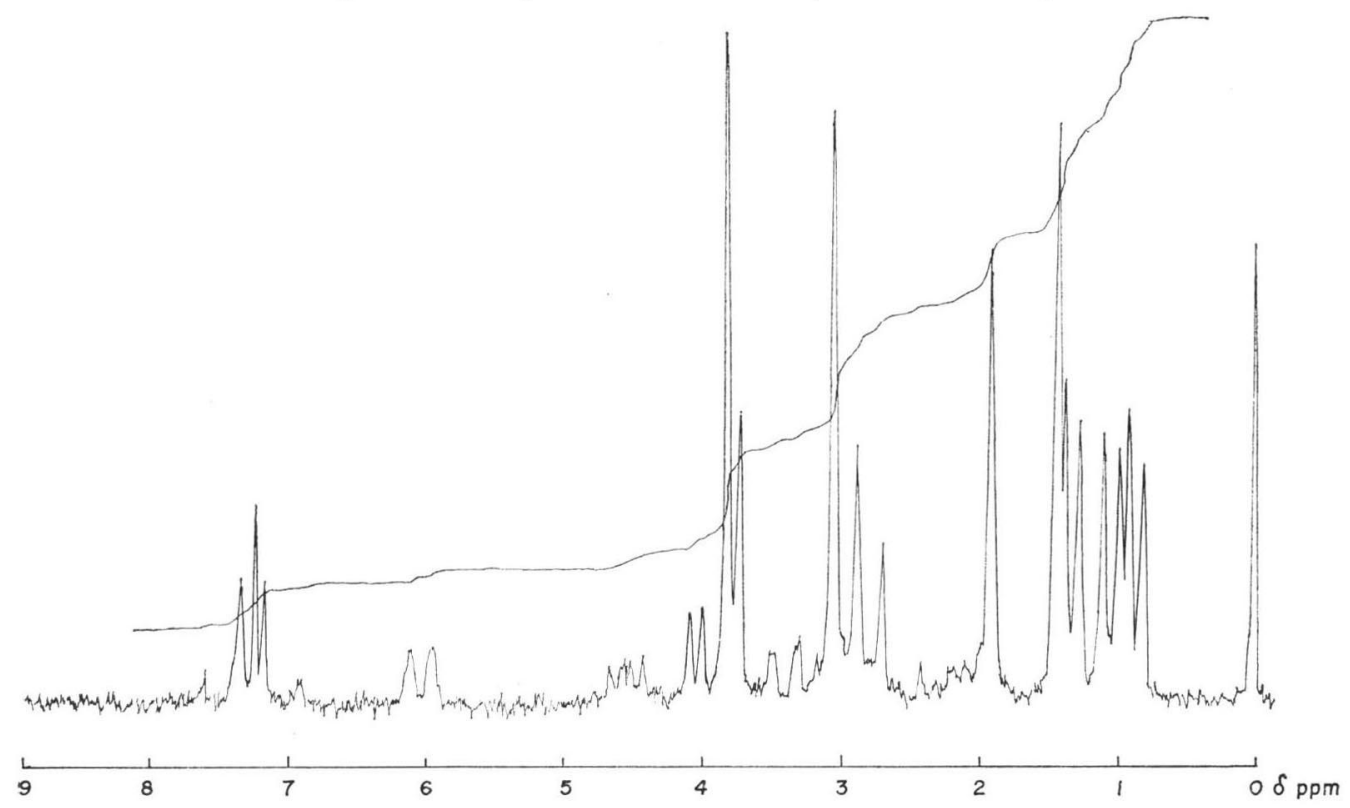

Fig. 6. NMR Spectrum of $\mathrm{Bu}-2313 \mathrm{~B}\left(60 \mathrm{MHz}\right.$ in $\left.\mathrm{CDCl}_{3}\right)$.

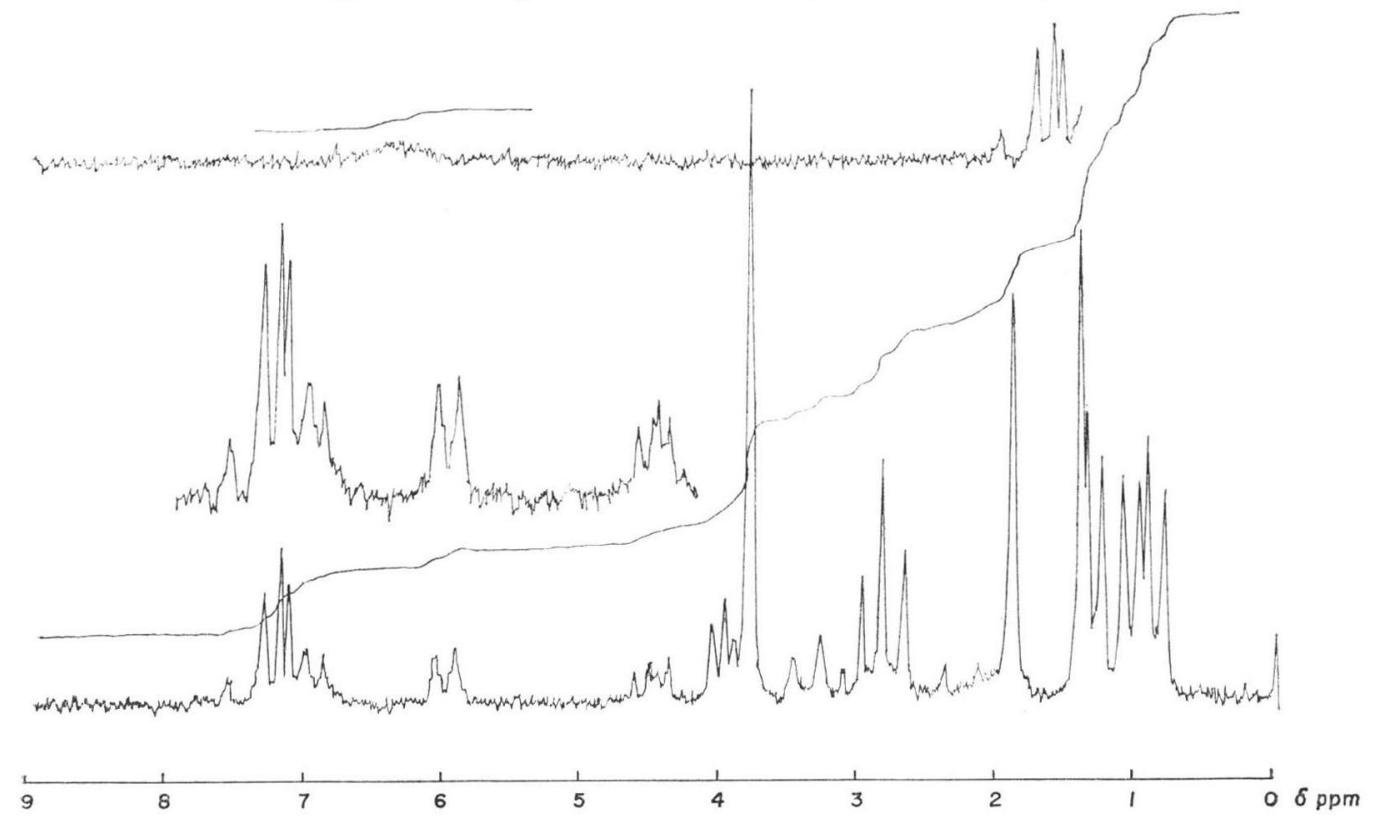

The UV spectra of Bu-2313 A and B taken in neutral, acidic and basic conditions are shown in Figs. 1 and 2, and the intensities of the absorption maxima are shown in Table 1. The hypsochromic shift of the UV maximum at $350 \sim 360 \mathrm{~nm}$ to $330 \sim 340 \mathrm{~nm}$ in going from acidic to alkaline $\mathrm{pH}$ is characteristic to that reported for the dienoyltetramic acid antibiotics ${ }^{6,7)}$.

The infrared spectra of Bu-2313 A and B in $\mathrm{KBr}$ pellet (Figs. 3 and 4) are similar to each other showing strong absorption bands at $1730,1660,1630,1580$ and $1210 \mathrm{~cm}^{-1}$. A sharp band at $1500 \mathrm{~cm}^{-1}$ 
is present in component $\mathrm{A}$ but not $\mathrm{B}$, while component $\mathrm{B}$ shows characteristic $\mathrm{N}-\mathrm{H}$ absorptions at $3200 \sim 3400 \mathrm{~cm}^{-1}$ which are absent in component A. The proton NMR spectra of $\mathrm{Bu}-2313 \mathrm{~A}$ and $\mathrm{B}$ (in $\mathrm{CDCl}_{3}$ ) are shown in Figs. 5 and 6. The NMR spectrum of component A showed an N-methyl signal at $\delta 3.03 \mathrm{ppm}$ which is absent in component $\mathrm{B}$.

\section{Biological Properties}

\section{In Vitro Antibacterial Activity}

The minimum inhibitory concentrations (MIC) of Bu-2313 A and B were determined for a variety of aerobic and anaerobic bacteria by the serial two-fold agar dilution method using a multi-inoculating apparatus. Nutrient agar medium (Eiken) was generally used for aerobic bacteria, GC medium (Eiken) for fastidious aerobic organisms such as streptococci, Neisseria and Hemophilus species, and GAM agar medium (Nissui) for anaerobic bacteria.

The in vitro antibacterial spectra of $\mathrm{Bu}-2313 \mathrm{~A}$ and $\mathrm{B}$ for aerobic organisms are shown in Table 2 and for anaerobic bacteria in Table 3. Against aerobic organisms Bu-2313 A and B inhibited the growth of various species of streptococci, Bacillus species, Neisseria meningitidis, $N$. gonorrhoeae and Hemophilus influenzae but showed only moderate to weak activity against aerobic organisms such as staphylococci and strains of Enterobacteriaceae. Bu-2313 A and B showed strong inhibitory activity against a wide range of anaerobic bacteria including Gram-positive and Gram-negative rods and cocci. The intrinsic in vitro activity of Bu-2313 B was approximately two times greater than that of Bu-2313 A.

The inhibitory potential of Bu-2313 A and B for two pathogenic species of Trichomonas, $T$. vaginalis and $T$. foetus, which are known to be anaerobic microorganisms, was also determined. The protozoa were grown at $37^{\circ} \mathrm{C}$ overnight in DiAMOND's medium containing $10 \%$ horse serum, $50 \mathrm{mcg} /$ $\mathrm{ml}$ of streptomycin and $150 \mathrm{mcg} / \mathrm{ml}$ of phenethicillin. A series of tubes containing two-fold dilutions of the test compounds in the above medium were inoculated with the protozoa (inoculum size: $10 \%$ ) and incubated overnight at $37^{\circ} \mathrm{C}$ to determine the MIC. Metronidazole (Flagyl, Shionogi) was tested as a reference compound. As shown in Table 4, Bu-2313 showed weak inhibitory activity against trichomonads.

Table 2. In vitro activity against aerobic bacteria.

\begin{tabular}{l|l|c|c|c}
\hline \multicolumn{1}{c|}{ Test organism } & Strain No. & $\begin{array}{c}\text { Test } \\
\text { medium* }\end{array}$ & \multicolumn{2}{|c}{ MIC (mcg/ml) } \\
\cline { 3 - 5 } Staphylococcus aureus & & Bu-2313 A & Bu-2313 B \\
"" & 209P & A & 25 & 25 \\
Sarcina lutea & Smith & A & 12.5 & 12.5 \\
Streptococcus pyogenes & PCI-1001 & A & 25 & 12.5 \\
Streptococcus viridans & A9604 & B & 0.8 & 0.4 \\
Streptococcus pneumoniae & A21354 & B & 0.8 & 0.4 \\
Bacillus subtilis & A9585 & B & 0.8 & 0.4 \\
Bacillus cereus & PCI-219 & A & 1.6 & 1.6 \\
Escherichia coli & ATCC 10702 A & A & 0.8 & 0.8 \\
Klebsiella pneumoniae & Juhl & A & $>100$ & $>100$ \\
Proteus morganii & A9678 & A & $>100$ & $>100$ \\
Neisseria meningitidis & A9553 & A & $>100$ & $>100$ \\
Neisseria gonorrhoeae & A20049 & B & 1.6 & 0.8 \\
Hemophilus influenzae & A15112 & B & 1.6 & 0.8 \\
\hline
\end{tabular}

* A: Nutrient agar (Eiken). B: GC medium (Eiken). 
Table 3. In vitro activity against anaerobic bacteria.

\begin{tabular}{|c|c|c|c|}
\hline \multirow{2}{*}{ Test organism } & \multirow{2}{*}{ Strain No. } & \multicolumn{2}{|c|}{$\begin{array}{c}\text { MIC }(\mathrm{mcg} / \mathrm{ml}) \\
\text { in GAM agar medium }\end{array}$} \\
\hline & & $\mathrm{Bu}-2313 \mathrm{~A}$ & $\mathrm{Bu}-2313 \mathrm{~B}$ \\
\hline Bacteroides fragilis & A20926 & 0.2 & 0.1 \\
\hline$"$ & A20928-1 & 0.1 & 0.1 \\
\hline$"$ & A20929 & 0.2 & 0.1 \\
\hline " & A20930 & 0.2 & 0.1 \\
\hline$"$ & A20932 & 0.2 & 0.1 \\
\hline " & A20935 & 0.2 & 0.1 \\
\hline Sphaerophorus necrophorus & $\mathrm{A} 15202$ & 0.2 & 0.1 \\
\hline Sphaerophorus pseudonecrophorus & A20013 & 0.2 & 0.1 \\
\hline Fusobacterium mortiferum & ATCC 9817 & 0.2 & 0.1 \\
\hline Fusobacterium varium & ATCC 8501 & 0.1 & 0.1 \\
\hline Acidoaminococcus fermentans & ATCC 25085 & 0.2 & 0.1 \\
\hline Veillonella parvula & ATCC 17745 & 0.2 & 0.1 \\
\hline Clostridium acetobutylicum & IAM 19011 & 0.4 & 0.2 \\
\hline Clostridium caproicum & IAM 19228 & 0.4 & 0.2 \\
\hline Clostridium chavoei & A9561 & 0.2 & 0.2 \\
\hline Clostridium perfringens & A9635 & 0.4 & 0.2 \\
\hline " " " & A21284 & 0.4 & 0.2 \\
\hline Peptococcus prevotii & ATCC 9321 & 0.2 & 0.1 \\
\hline Peptococcus aerogenes & ATCC 14963 & 0.2 & 0.2 \\
\hline Peptostreptococcus anaerobius & $\mathrm{B} 43$ & 0.4 & 0.4 \\
\hline
\end{tabular}

Table 4. Antitrichomonas activity of Bu-2313 A and B.

\begin{tabular}{l|c|c|c}
\hline \multirow{2}{*}{ Organism } & \multicolumn{3}{|c}{ MIC (mcg/ml) } \\
\cline { 2 - 4 } & Bu-2313 A & Bu-2313 B & $\begin{array}{c}\text { Metro- } \\
\text { nidazole }\end{array}$ \\
\hline T. vaginalis 1099 & 12.5 & 50 & 0.8 \\
T. foetus Inui & 12.5 & 25 & 0.8 \\
\hline
\end{tabular}

\section{In Vivo Experiments}

The effectiveness of Bu-2313 A and B in vivo was assessed in experimental infections of mice produced by two anaerobic bacteria, Bacteroides fragilis and Clostridium perfringens, and by one aerobic pathogen, Streptococcus pyogenes.

A localized infection of B. fragilis A20926 was established ${ }^{8)}$ by subcutaneous injection into the dorsal area of the neck of mice with $0.5 \mathrm{ml}$ of the bacterial suspension containing $2 \sim 5 \times 10^{6}$ cells and $10 \mathrm{mg}$ of microcrystalline cellulose. Treatment was given subcutaneously at the lower back or orally once daily for 5 consecutive days starting 30 minutes after the challenge. A group of five mice was used at each dosage level and the animals were dissected on the 6th day to measure the size of the subcutaneous abscess. The response in each animal was scored as $0 \sim 5$ according to the size of lesion, and the sum of the lesion scores was divided by the number of mice used per group to obtain the mean score for each of the treatment and control groups. Taking the mean score of the control group as the $100 \%$ infectivity level, the relative infection level was calculated for each of the treatment groups and a $\mathrm{PD}_{50}$ (protective dose, $50 \%$ ) was then estimated by means of log-probit plot. As shown in Table 5, Bu-2313 B and metronidazole were effective in this infection model with somewhat greater activity 
demonstrated by the latter compound.

The systemic infection of $C$. perfringens A9635 was produced in mice by intraperitoneal challenge with a lethal dose of the pathogen given in a $5 \%$ suspension of hog gastric mucin (Americal Laboratories, Omaha, Neb.). The antibiotic was administered subcutaneously or orally just before the bacterial challenge. The $\mathrm{PD}_{50}$ was determined after 5 days. As shown in Table 6, Bu-2313 B gave fairly good protection against the infection by both subcutaneous and oral routes, while Bu2313 A was comparably active by the subcutaneous route but less effective than $\mathrm{Bu}-2313$ B by the oral route. Metronidazole was less active than $\mathrm{Bu}-2313$ in this anaerobic infection model.

Bu-2313 A and B were also tested in the Streptococcus pyogenes A20201 systemic infection by a procedure similar to that used to produce the above-described Clostridium perfringens infection. As shown in Table 7, Bu-2313 B showed activity by both subcutaneous and oral routes, while $\mathrm{Bu}-2313$ A was only active parenterally.

Blood levels were determined in mice following subcutaneous or oral administration of $\mathrm{Bu}-2313$ B. Blood samples were collected from orbital sinuses and assayed by the paper disc-agar plate method using B. fragilis A20926 as the test organism. As shown in Table 8, Bu-2313 B was fairly well ab-

Table 5. In vivo activity against localized infection with B. fragilis.

\begin{tabular}{|c|c|c|}
\hline \multirow{2}{*}{$\begin{array}{c}\text { Subcutaneous } \\
\text { dose }(\mathrm{mg} / \mathrm{kg} / \text { day })\end{array}$} & \multicolumn{2}{|c|}{ Infectivity level (\%) } \\
\hline & $\mathrm{Bu}-2313 \mathrm{~B}$ & Metronidazole \\
\hline $50 \times 5$ & 52.4 & 47.6 \\
\hline $12.5 \times 5$ & 66.7 & 57.1 \\
\hline $3.1 \times 5$ & 81.0 & 81.0 \\
\hline $0.8 \times 5$ & 95.2 & 95.2 \\
\hline $\mathrm{PD}_{50}(\mathrm{sc})$ & $60 \mathrm{mg} / \mathrm{kg}$ & $35 \mathrm{mg} / \mathrm{kg}$ \\
\hline \multirow{2}{*}{$\begin{array}{c}\text { Oral dose } \\
(\mathrm{mg} / \mathrm{kg} / \text { day) }\end{array}$} & \multicolumn{2}{|c|}{ Infectivity level $(\%)$} \\
\hline & Bu-2313 B & Metronidazole \\
\hline $100 \times 5$ & 57.1 & 38.1 \\
\hline $25 \times 5$ & 71.4 & 61.9 \\
\hline $6.3 \times 5$ & 81.0 & 81.0 \\
\hline $1.6 \times 5$ & 95.2 & 95.2 \\
\hline $\mathrm{PD}_{50}(\mathrm{po})$ & ca. $200 \mathrm{mg} / \mathrm{kg}$ & $50 \mathrm{mg} / \mathrm{kg}$ \\
\hline
\end{tabular}

Table 7. In vivo activity against $S$. pyogenes infection.

\begin{tabular}{l|c|c}
\hline \multirow{2}{*}{$\begin{array}{c}\text { Route of } \\
\text { administration }\end{array}$} & \multicolumn{2}{|c}{$\mathrm{PD}_{50}(\mathrm{mg} / \mathrm{kg})^{*}$} \\
\cline { 2 - 3 } & $\mathrm{Bu}-2313 \mathrm{~A}$ & $\mathrm{Bu}-2313 \mathrm{~B}$ \\
\hline Subcutaneous & 7.6 & 9.0 \\
Oral & $\mathrm{NA}^{* *}$ & 25 \\
\hline$* \quad$ single treatment \\
$* * \quad$ no activity at $25 \mathrm{mg} / \mathrm{kg}$
\end{tabular}
sorbed in mice after both subcutaneous and oral dosing.

The acute toxicity of Bu-2313 A and B was determined in mice by the subcutaneous route. $\mathrm{Bu}-2313 \mathrm{~B}$ was found to be less toxic than $\mathrm{Bu}-$ $2313 \mathrm{~A}$ : The subcutaneous $\mathrm{LD}_{50}$ was $90 \mathrm{mg} / \mathrm{kg}$ for $\mathrm{Bu}-2313 \mathrm{~A}$ and $320 \mathrm{mg} / \mathrm{kg}$ for $\mathrm{Bu}-2313 \mathrm{~B}$.

Table 6. In vivo activity against systemic infection with $C$. perfringens.

\begin{tabular}{l|c|c|c}
\hline \multirow{2}{*}{$\begin{array}{c}\text { Route of } \\
\text { administration }\end{array}$} & $\begin{array}{c}\mid c \\
\mathrm{Bu}-2313 \\
\mathrm{~A}\end{array}$ & $\begin{array}{c}\mathrm{Bu}-2313 \\
\mathrm{~B}\end{array}$ & $\begin{array}{c}\text { Metro- } \\
\text { nidazole }\end{array}$ \\
\cline { 2 - 4 } Subcutaneous & 6.3 & 6.3 & 31 \\
Oral & $>50$ & 30 & 60 \\
\hline
\end{tabular}

* single treatment

Table 8. Blood levels in mice.

\begin{tabular}{c|c|c}
\hline \multirow{2}{*}{$\begin{array}{c}\text { Time after } \\
\text { administration }\end{array}$} & \multicolumn{2}{|c}{$\begin{array}{c}\text { Blood levels of Bu-2313 B } \\
\text { (mcg/ml) }\end{array}$} \\
\cline { 2 - 3 } & $\begin{array}{c}\text { Subcutaneous } \\
\text { dose of } \\
25 \mathrm{mg} / \mathrm{kg}\end{array}$ & $\begin{array}{c}\text { Oral } \\
\text { dose of } \\
100 \mathrm{mg} / \mathrm{kg}\end{array}$ \\
\hline $15 \mathrm{~min}$. & 12 & \\
$30 \mathrm{~min}$. & 10 & 12 \\
$1 \mathrm{hr}$. & 4.6 & 5.5 \\
$2 \mathrm{hrs}$. & 0.9 & \\
$3 \mathrm{hrs}$. & & 0.4 \\
5 hrs. & & 0.3 \\
\hline
\end{tabular}




\section{Discussion}

Bu-2313 A and B showed characteristic UV spectra which are similar to those of the dienoyltetramic acid antibiotics, streptolydigin and tirandamycin. A companion paper ${ }^{3)}$ indicates that Bu-2313 A and B do in fact have an acyltetramic acid structure. Bu-2313 A and B, streptolydigin and tirandamycin were differentiated from each other using three TLC systems as shown in Table 9. Although the antianaerobic activity of streptolydigin and tirandamycin against Clostridium species has been described, these two antibiotics were also detected in our anti-anaerobic screening program and found to be active against many anaerobic bacteria including B. fragilis. Recently, a new member of this group of antibiotics was reported under the name of nocamycin from Russian scientists ${ }^{9)}$. The physico-chemical properties and spectral data of nocamycin $^{10)}$ are very close to those of $\mathrm{Bu}-2313 \mathrm{~B}$, but the structure assigned to nocamycin ${ }^{11)}$ is different from that of Bu-2313 $\mathrm{B}^{3)}$.

\section{References}

1) Meyer, R. D. \& S. M. Finegold: Anaerobic infections: diagnosis and treatment. South. Med. J. 69: $1178 \sim 1195,1976$

2) BlazeVIC, D. J.: Antibiotic susceptibility of subspecies of Bacteroides fragilis. Antimicr. Agents \& Chemoth. 9: $481 \sim 484,1976$

3) Tsunakawa, M.; S. Toda, T. Okita, M. Hanada, S. Nakagawa, H. Tsukiura, T. Naito \& H. Kawaguchi: Bu-2313, a new antibiotic complex active against anaerobes. II. Structure determination of Bu-2313 A and B. J. Antibiotics 33: $166 \sim 172,1980$

4) Rinehart, Jr., K. L.; J. R. Beck, D. B. Borders, T. H. Kinstle \& D. Krauss: Streptolydigin. III. Chromophore and structure. J. Am. Chem. Soc. 85: 4038 4039, 1963

5) MacKellar, F. A.; M. F. Grostic, E. C. Olson, R. J. Whuk, A. R. Branfman \& K. L. Rinehart, Jr.: Tirandamycin. I. Structure assignment. J. Am. Chem. Soc. 93: 4943 4945, 1971

6) Eble, T. E.; C. M. Large, W. H. DeVries, G. F. Crum \& J. W. Shell: Streptolydigin: A new antimicrobial antibiotic. II. Isolation and characterization. Antibiotics Ann. 1955/1956: 893 896, 1956

7) Meyer, C. E.: Tirandamycin, a new antibiotic. Isolation and characterization. J. Antibiotics 24: 558 560,1971

8) Chisholm, D. R.: Personal communication.

9) Gauze, G. F.; M. A. Sveshnikova, R. S. Ukholina, G. N. Komarova \& V. S. Bazhanov: Production of nocamycin, a new antibiotic by Nocardiopsis syringae sp. nov. Antibiotiki 22: 483 486, 1977

10) Brazhnikova, M. G.; N. V. Konstantinova, N. P. Potapova \& I. V. Tolstykh: Physico-chemical characteristics of nocamycin, a new antitumor antibiotic. Antibiotiki 22: 486 489, 1977

11) Horváth, G.; M. G. Brazhnikova, N. V. Konstantinova, I. V. Tolstykh \& N. P. Potapova: The structure of nocamycin, a new antitumor antibiotic. J. Antibiotics 32: 555 558, 1979 